URL: http://ojs.unimal.ac.id/index.php/ekonomi_regional

\title{
Pengaruh Harga Minyak Dunia dan Suku Bunga Terhadap Pertumbuhan Ekonomi Indonesia Tahun 1987-2017
}

\author{
${ }^{* a}$ Ina Yanti, ${ }^{*}$ Ratna \\ * Fakultas Ekonomi dan Bisnis Universitas Malikussaleh \\ a Corresponding author:inay3071@gmail.com \\ bratna@uimal.com
}

\section{A R T I CLE I N F OR MA T I ON}

Keywords:

World Oil Prices, Interest Rates, and Economic Growth.

\section{A B S T R A C T}

This study aims to determine the effect of world oil prices and interest rates on the Indonesian economic growth. The data used in this study is time-series data during1987-2017. The study uses multiple linear regression and Vector Autoregression (VAR) models. The results of the study showed that partially the world oil prices and interest rates have a significant and negative effect on the Indonesian economic growth. Simultaneously, world oil prices and interest rates have a significant and positive effect on the economic growth of Indonesia. Furthermore, the results of testing the VAR analysis model indicate that world oil prices has a positive and significant effect on the Indonesian economic growth, and interest rates has a positive and insignificant effect on the Indonesian economic growth. It recommends that the government and all stakeholders must collaborate to reduce or eliminate the influence of shocks to global oil prices domestically and a particular policy to normalize the price of fuel.

\section{PENDAHULUAN}

Pertumbuhan ekonomi dunia pada tahun 2017 mengalami peningkatan, akibat pemulihan berlanjut pada investasi, manufaktur, dan perdagangan, serta juga negara-negara berkembang yang mengekspor komoditas mendapatkan keuntungan dari menguatnya harga komoditas lain.

Namun, ini sebagai besar dilihat dari jangka pendek. Dalam jangka panjang, melambatnya potensi pertumbuhan, yaitu sebuah ukuran seberapa cepat sebuah ekonomi dapat berkembang ketika tenaga kerja dan modal dipekerjakan sepenuhnya. Pertumbuhan ekonomi di negara berkembang khusunya Indonesia pada tahun 2014-2017 terus mengalami perlambatan yang diakibatkan ogle beberapa sektor ekonomi menurun baik dari sektor pertambangan maupun industry pengolahan. Sehingga Indonesia harus mencari stategi untuk meningkatkan pertumbuhan ekonominya.

Perkembangan pertumbuhan ekonomi tahun 2008-2017 dapat di lihat dari gambar 1 di bawah ini :

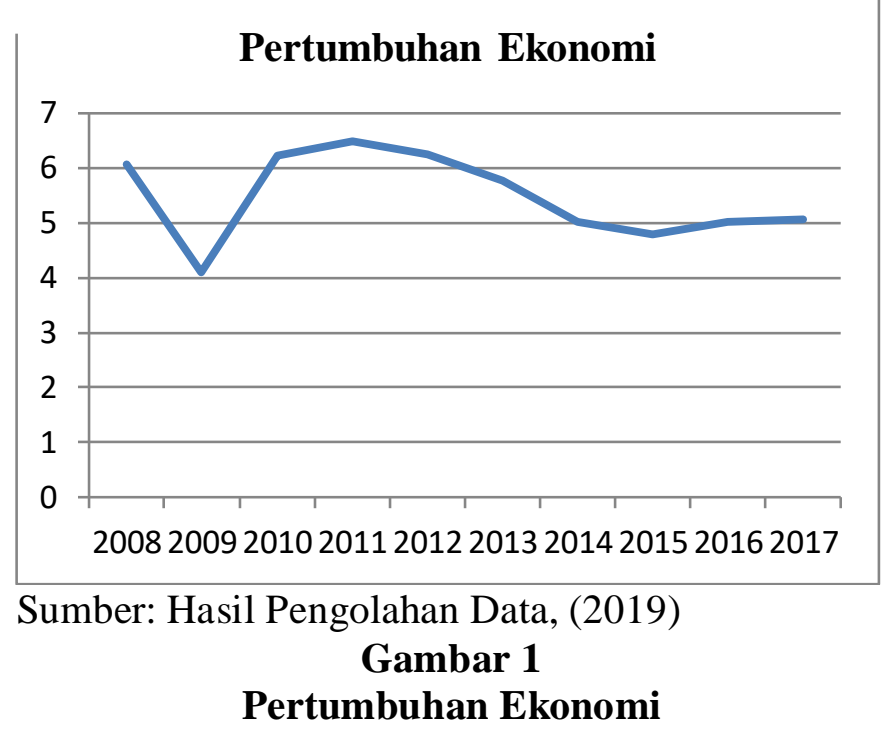

Di lihat dari gambar 1 di atas dapat di lihat perkembangan pertumbuhan ekonomi Indonesia tahun 2008-2017, pertumbuhan ekonomi tahun 2008-2009 mengalami penurunan dari 6,06 persen sampai 4,10 persen sebagai dampak perlambatan ekonomi global,Sedangkan pada tahun 2010 sampai 2011 pertumbuhan ekonomi mengalami peningkatan sebesar 6,22 peren sampai 6,49 persen, pada tahun 2012 sampai tahun 2015 pertumbuhan ekonomi mengalami penurunan yang signifikan, karena penyebab konsumsi rumah tangga, pada 
tahun 2016-2017 pertumbuhan ekonomi mengalami peningkatan sebesar 5,02 persen sampai 5,07 persen, penelitian ini sesuai dengan penelitian dari (Septiawan dkk, 2016).

Pertumbuhan ekonomi pada tahun terakhir dalam penelitian mengalami peningkatan salah satu faktor penyumbangnya adalah industri pengolahan, sektor kontruksi, sektor perdaganga dan pertanian. Pada dasarnya dengan meningkatnya perekonomian tersebut dapat menyerap banyak tenaga kerja dan memberikan kontribusi yang sangat besar sekali bagi Indonesia.

Salah satu sektor yang memberikan kontribusi besar terhadap perekonomian Indonesia sektor Migas. Namun Indonesia menjadi salah satu net importer minyak dunia karena cadangan minyak Indonesia tidak mampu memenuhi kebutuhan konsumsi masyarakatnya yang menyebabkan ekonomi Indonesia rentan terhadap perkembangan harga minyak yang berfluktuatif (Irham, 2018). Perkembangan Harga Minyak Dunia dari tahun 2008-2017 dapat kita lihat pada gambar 2 di bawah ini :

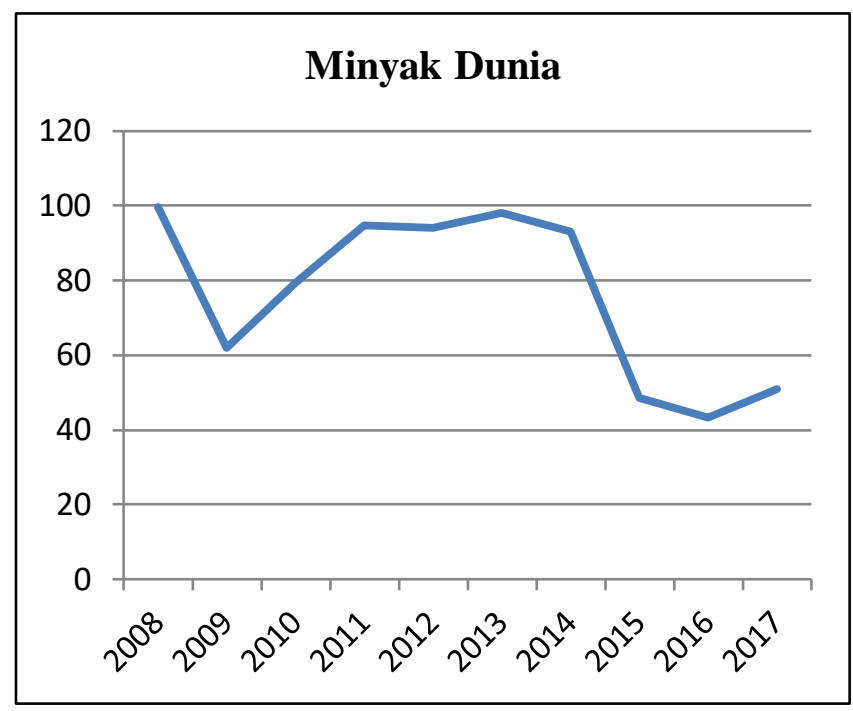

Sumber: Hasil Pengolahan Data, (2019)

Gambar 2

Minyak Dunia

Berdasarkan gambar 2 di atas perkembangan Harga minyak dunia pada tahun 2008-2017 terus mengalami fluktuasi pada tahun 2008 minyak dunia mengalami peningkatan sebesar 99,67 Dollar barrel, dan pada tahun 2009 mengalami penurunan sebesar 61,95 Dollar barrel, Sedangkan pada tahun 2010 sampai 2013 terus menglami peningkatan sebesar 79,48 Dollar barrel sampai 94,00 Dollar barrel, dan pada tahun 2014 mengalami penurunan sebesar 93,17 Dollar barrel.
Pada tahun 2015 minyak dunia mengalami penurunan yang sangat drastis yaitu sebesar 48,66 Dollar barrel di sebabkan oleh tiga faktor yaitu pertama, pasokan berlebihan karena Amerika Serikat melakukan revolusi energy sehingga menyebabkan banjirnya pasokan minyak. Kedua, permintaan menurun penyebab utamanya dating dari negara China yang saat ini sedang mengalami perlambatan ekonomi dan membuat harga komoditas dunia menurun, termasuk harga minyak mentah. Ketiga, kenaikan nilai Dollar Amerika akibatnya ketika nilainya naik maka harganya pun akan naik. Bagi Indonesia sendiri, akibat dari kenaikan minyak ini maka akan menguntungkan perusahaan minyak di Indonesia seperti ELSA, BIPI, dan MEDC akan diuntungkan dari kenaikan tersebut (Detikfinance, 2019).

Sedangkan pada tahun 2016 juga mengalami penurunan sebesar 43,29 Dollar barrel ini tidak sesuai dengan teori, karena apabila harga miyak dunia meningkat maka pertumbuhan ekonomi meningkat sedangkan yang terjadi pada tahun 2016 harga minyak dunia menurun dan pertumbuhan ekonomi meningkat, ini jelas tidak sesuai dengan teori, dan pada tahun 2017 harga minyak dunia kembali meningkat menjadi 50,8 Dollar barrel.

Penguatan harga minyak pada tahun terakhir disebabkan oleh dua faktor yaitu pertama, tingkat produksi OPEC yang stabil, yang berujung pada penyesuaian yang sangat mengagumkan (dengan kesepakatan pemotongan pasokan). Kedua, perkembangan pasokan dari sisi geopolitik di Venezuela, Libya dan Iran (Voaindonesia, 2019). Dengan peningkatan harga minyak tersebut dapat meningkatkan pertumbuhan ekonomi di suatu negara.

Selain kecenderungan harga minyak dunia meningkat, Otoritas Jasa Keuangan (OJK) memprediksi suku bunga juga berpotensi naik. Suku bunga merupakan tolak ukur kegiatan perekonomian dari suatu negara yang akan berimbas pada kegiatan perputaran arus keuangan perbankan, inflasi, investasi dan pergerakan currency). Perkembangan Suku bunga dapat kita lihat pada Gambar 3 di bawah ini : 


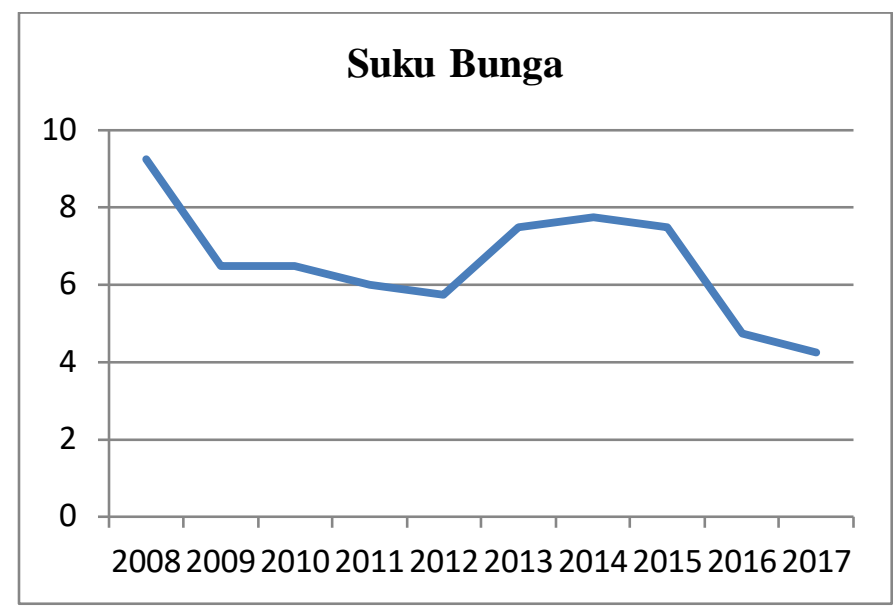

Sumber: Hasil Pengolahan Data, (2019)

Gambar 3

Suku Bunga

Berdasarkan grafik 3 di atas perkembangan suku bunga pada tahun 2008-2017 terus mengalami fluktuasi, pada tahu 2008 mengalami peningkatan sbesar 9,25 persen karena dampak dari kenaikan harga BBM dan pada tahun 20092010 suku bunga berada di kisaran 6,5 persen. Sedangakan pada tahun 2011-2012 suku bunga mengalami penurunan mencapai angka 5,75 persen. Pada tahun 2016 dan 2017 suku bunga mengalami penurunan dari 4,75 persen menjadi 4,25 persen.

Penurunan suku bunga pada tahun 2016 sampai pada tahun 2017 yang dilakukan oleh Bank Indonesia dengan harapan agara seluruh bunga acuan ini diikuti dengan pengurungan suku Bunga kredit perbankan serta likuiditas menyebar ke sektor rill. Serta penuruan suku bunga kredit ini diharapkan dapat mendongkrak investasi guna meningkatkan pertumbuhan ekonomi Indonesia.

Ada empat hal yang menjadi latar belakang Bank Sentral menurunkan suku bunga acuan. Pertama, faktornya yaitu inflasi yang rendah pada tahun 2017, dengan inflasi yang rendah membuka ruang kebijakan penurunan suku bunga ini sesuai dengan kebijakan moneter. Kedua, defisit transaksi berjalan tetap terkendali dari PDB. Ketiga, faktor risiko eksternal mereda, utamanya dari arah kebijakan Bank Sentral AS Federal Reserve (The Fed). Alasan keempat, dengan penurunan suku bunga acuan dapat mendorong penyaluran kredit perbankan sekaligus mendukung pertumbuhan ekonomi secara berkelanjutan (Bank Indonesia, 2019).

Berdasarkan penelitian sebelumnya yang berkaitan dengan pengaruh harga minyak dunia inflasi, dan nilai tukar terhadap pertumbuhan ekonomi telat di teliti oleh (Septian dkk, 2016), Pengaruh harga minyak dunia, harga emas, dan tingkat inflasi terhadap pertumbuhan ekonomi (Ningtyas \& Arum, 2014), pengaruh harga minyak dunia, nilai tukar dan inflasi terhadap pertumbuhan ekonomi indonesia (Arifin, 2018) yang memberikan fokus pada harga minyak dunia, selanjutnya penelitian yang memberikan fokus pada analisis pengaruh inflasi dan suku bunga terhadap pertumbuhan ekonomi di Indonesia yang di teliti oleh (Indriyani, 2016), pengaruh inflasi tingkat suku bunga, dan nilai tukar terhadap pertumbuhan ekonomi (Susanto, 2014)

Sejauh ini penelitian yang terkait dengan fokus yang peneliti lakukan masih sedikit di jumpai dalam publikasi, dapat di lihat pada penelitian terdahulu dan masih sedikit yang menggabungkan variabel harga minyak dunia dan suku bunga terhadap pertumbuhan ekonomi di indonesia tahun 1987-2017. Oleh karena itu peneliti tertarik untuk melakukan penelitian ini.

Tujuan penelitian adalah untuk melihat pengaruh harga minyak dunia dan suku bunga terhadap pertumbuhan ekonomi. Selanjutnya bagian kedua penelitian ini membahas tinjauan teoritis di variabel-variabel terkait, pembatasan kajian dan teknik analisis yang dipaparkan dibagian tiga, untuk melihat hasil dan analisis dipaparkan pada bagian ke empat, akhirnya kesimpulan dan saran di bagian ke lima dari penelitian ini.

\section{TINJAUAN TEORITIS}

\section{Pertumbuhan Ekonomi}

Pertumbuhan ekonomi merupakan suatu proses peningkatan kapasitas produktif dalam perekonomian secara terus menerus atau berkesinambungan sepanjang waktu sehingga menghasikan tingkat pendapatan dan output nasional yang semakin lama semakin besar (Antasari \& Soleh, 2012).

Berdasarkan pendapat para pakar di atas, maka pertumbuhan ekonomi adalah suatu proses perubahan kondisi perekonomian suatu negra secara berkesinambungan menuju keadaan yang lebih baik dengan di tandainya adanya kenaikan pendapatan Nasional selama periode tertentu.

Teori pertumbuhan ekonomi klasik memandang proses pembangunan ekonomi dari sisi penawaran. Namun teori pertumbuhan ekonomi Keynes menegaskan dari sisi permintaan yaitu permintaan efektif menentukan tingkat keseimbangan dan pendapatan nasional. Pengeluaran yang dilakukan oleh sektor rumah tangga, pengusaha, dan pemerintah serta sektor luar negeri dapat meningkatkan permintaan agregat dan pendapatan nasional (Jhingan, 2000). 


\section{Harga Minyak Dunia}

Harga minyak dunia merupakan harga minyak mentah dunia yang terbentuk karena permintaan dan penawaran komoditas minyak dunia. Harga minyak dunia biasanya di hitung dalam US dollar per barrel ( 1 barrel = 159 liter), dengan menggunakan rata-rata harga minyak yang telah di sesuaikan dengan kurs rupiah yang berlaku dengan, masing-masing tahun sehingga hasilnya berbentu mata uang rupiah(Ningtyas \& Hidayat, 2014).Minyak mentah atau crude oil merupakan salah satu energi utama yang sangat dibutuhkan (Kurihara, 2015).

Menurut Tang \& Zhang, (2010)jika harga dollar Amerika Serikat mengalami peningkatan ini menyebabkan harga minyak dunia mengalami peningkatan juga akibat dari peningkata minyak ini akan menguntungkan perusahaan minyak dunia di Indonesia sehingga dapat memberikan sumbangan kepada pertumbuhan ekonomi. hubungan antara harga minyak dunia terhadap pertumbuhan ekonomi yaitu berpengaruh positif.

Anderu, (2018)dengan judul an empirical nexus between oil price collapse and economic growth in sub-saharan African oil based economies, hasil penelitian menunjukkan bahwa ada hubungan negatif antara jatuhnya harga minyak dan pertumbuhan ekonomi dalam kasus Angola, Nigeria dan Sudan. Persamaanya samasama menggunakan variabel minyak dunia dan pertumbuhan ekonomi, perbedaannya penelitian terdahulu menggunakan metode REM, sedangkan penelitian penulis menggunkan metode OLS dan VAR.

\section{Suku Bunga}

Menurut Mishkin, (2008) suku bunga adalah biaya pinjaman atau harga yang di bayarkan untuk dana pinjaman tersebut (biasanya di nyatakan sebagai presentase per unit). Menurut Brigham \& Houston, (2001) suku bunga adalah harga yang harus di bayar atas modal pinjaman, dan deviden serta keuntungan modal yang merupakan hasil dari modal ekuitas.

Menurut Boediono, (2002) dimana makin tinggi tingkat bunga makin tinggi pula keinginan masyarakat untuk menabung Investasi juga merupakan fungsi dari tingkat bunga, dimana makin tinggi tingkat bunga maka keinginan berinvestasi makin kecil sehingga pertumbuhan ekonomi meningkat. Makin rendah tingkat bunga maka akan mendorong para investor untuk berinvestasi karena biaya yang ditanggung semakin kecil dengan harapan profit yang maksimum. Jadi hubungan antara suku bunga terhadap pertumbuhan ekonomi yaitu positif.

Jika dibandingkan penelitian penulis dengan penelitian sebelumnya yaitu menurut Indriyani, (2016) dengan judul penelitian Gylych, (2016)dengan judul the impact of interest rte on economic growth exemple of Nigeria, peneliti ini menyimpulkan bahwa di negeria tingkat suku bunga memiliki dampak signifikan, pada pertumbuhan ekonomi, hasil analisis statistic menunjukkan bahwa unit berubah dalam investasi menunjukkan bahwa unit berubah dalam investasi akan mengarah pada pertumbuhan. Studi ini menghasilkan bukti empiri yang akan membantu. Persamaannya sama-sama menggunakan variabel suku bunga dan pertumbuhan ekonomi, perbedaannya penelitian terdahulu menggunakan metode OLS sedangkan penulis mengunakan OLS dan VAR.

\section{Kerangka Konsptual}

Berdasarkan landasan teori dan kajian terhadap penelitian terdahulu, maka disusun suatu kerangka pemikiran teori mengenai penelitian yang akan dilakukan. Kerangka pemikiran teori dapat dilihat pada Gambar 4.

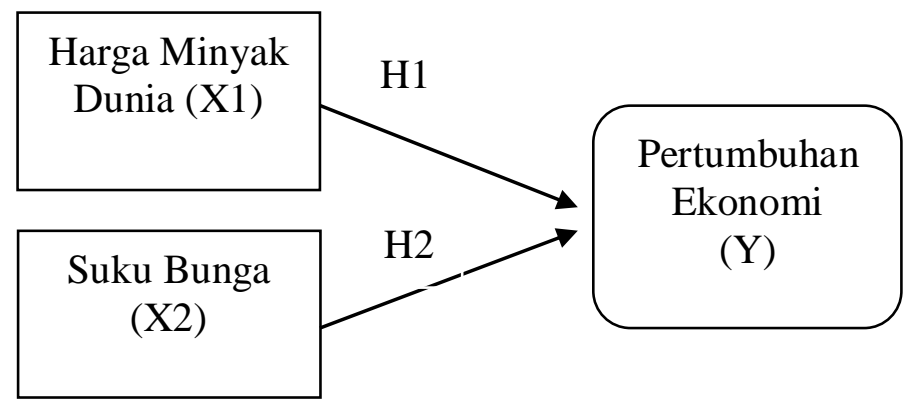

\section{Gambar 4 \\ Kerangka Konseptual}

\section{Hipotesis}

H1 : Diduga harga minyak dunia berpengaruh positif dan signifikan terhadap pertumbuhan ekonomi di Indonesia.

H2 : Diduga suku bunga berpengaruh positif dan signifikan terhadap pertumbuhan ekonomi di Indonesia.

\section{METODE PENELITIAN}

\section{Data dan Sumber Data}

Jenis data yang digunakan dalam penelitian ini adalah data kuantitatif. Yaitu data yang dapat diukur dalam skala numerik atau dalam bentuk angka. Dalam penelitian ini penulis menggunakan 
data sekunder dengan bentuk data time-series yaitu dalam bentuk tahunan dengan tahun pengamatan dari tahun 1986-2016.

\section{Operasional Variabel}

Operasional variabel adalah petunjuk tentang bagaimana cara mengukur suatu variabel dalam penelitian. Dalam penelitian ini terdapat dua variabel yaitu terikat (Dependen) dan variabel bebas (Independen).

1. Pertumbuhan Ekonomi (Y) adalah adalahsuatu proses perubahan kondisi perekonomian suatu negara secara berkesenambungan menuju keadaan yang lebih baik dengandi tandainya adanya kenaikan pendapatan Nasional selama periode tertentu diukur dalam satuan persen $(\%)$.

2. Minyak Dunia (X1) adalah Minyak mentah atau crude oil merupakan salah satu energy utama yang sangat dibutuhkan. Hasil dari pengolahan minyak mentah dapat menjadi energi untuk melakukan kegiatan produksi dalam satuan U\$ dollar per barrell.

3. Suku bunga (x2) merupakan sebuah balas jasa yang di berikan kepada seseorang atau lembaga atas dasar modal yang di tanamkan atau di pinjamkan seseorang atau lembaga tersebut kepada pihak pemberi modal atau peminjam modal dalam bentuk persentase dalam satuan persen $(\%)$.

\section{Metode Analisa Data}

\section{Model Regresi Lineir Ordinary Least Square (OLS)}

Untuk mengetahui pengaruh harga minyak dan suku bunga terhadap pertumbuhan ekonomi di Indonesia maka, metode yang digunakan dalam penelitian ini adalah uji regresi linear berganda baik secara simultan maupun parsial. Adapun rumus regresi linear berganda adalah sebagai berikut:

\section{Dimana:}

$$
Y_{t}=\beta_{0}+b_{1} X_{1} \mathrm{t}+b_{2} X_{2} \mathrm{t}+\mathrm{et}
$$

$$
\begin{array}{ll}
Y_{t} & : \text { pertumbuhan ekonomi } \\
\beta_{0} & : \text { Konstanta } \\
X_{1} & : \text { harga minyak } \\
X_{2} & : \text { suku bunga } \\
\beta_{1}-\beta_{2} & : \text { Koefisien regresi masing-masing }
\end{array}
$$
variabel independen
e
: error term
$t$
: Periode waktu

Tahapan pengujian dalam OLS Adalah sebagai berikut:

\section{Uji Normalitas}

Uji normalitas adalah untuk mengetahui apakah residual berdistribusi secara normal atau tidak. Pengujian normalitas dapat dilakukan dengan menggunakan metode Jarque-Bera (J-B) (Gujarati, 2004). Jika nilai probability dari statistik J-B lebih besar dari taraf kepercayaan $5 \%(0,05)$ berarti bahwa residual data berdistribusi normal. Sebaliknya jika nilai probability dari statistik J-B lebih kecil dari taraf kepercayaan 5\% $(0,05)$.

\section{Uji Asumsi Klasik}

Menurut Gujarati, (2004) uji asumsi klasik adalah sebagai berikut:

\section{UjiMultikolinearitas}

Uji multikolinearitas adalah hubungan linear yang terjadi diantara variabel-variabel independen. Pengujian terhadap gejala multikolinearitas dapat dilakukan dengan menghitung variance inflation factor (VIF) dari hasil estimasi. Jika VIF $<10$, Maka antara variabel independen tidak terjadi hubungan yang linear (tidak ada multikolinearitas). Multikolinearitas dalam penelitian ini diuji dengan melihat nilai tolerance dan variance inflation factor (VIF). Apabila nilai VIF $<10$ maka diduga tidak ada multikolinearitas. Begitupula nilai tolerance yang mendekati satu maka bisa disimpulkan juga tidak ada masalah multikolinearitas (Gujarati, 2003).

\section{Uji Autokorelasi}

Menurut Firdaus (2004), autokorelasi merupakan gangguan pada fungsi regresi yang berupa korelasi diantara faktor gangguan.Ada tidaknya autokorelasi juga dapat dilihat dari nilai probabilitas Chi-Square $\left(x^{2}\right)$. Jika nilai probabilitas lebih besar dari nilai $\alpha$ yang dipilih maka kita menerima $H_{0}$ yang berarti tidak ada autokorelasi. Sebaliknya jika nilai probabilitas lebih kecil dari nilai $\alpha$ yang dipilih maka kita menolak $H_{0}$ yang berarti ada masalah autokorelasi (Widarjono, 2017).

\section{Uji Heteroskedastisitas}

Uji Heteroskedastisitas bertujuan menguji apakah dalam model regresi terjadi ketidaksamaan variance dari residual satu pengamatan ke pengamatan yang lain (Ghozali, 2007).Metode pengujian yang lain dapat digunakan adalah metode White dimana hipotesis Heteroskedastisitas yang dipakai:

Ho: tidak ada heteroskedastisitas $(>0,05)$ 
Ha: ada heteroskedastisitas $(<0,05)$

\section{Pengujian Statistik}

\section{Uji statisti t (Uji Parsial)}

Uji t dilakukan untuk melihat signifikansi dari pengaruh variabel bebas secara individu terhadap variabel terikat dengan menganggap variabel bebas lainnya adalah konstan (Gujarati, 2006). Adapun kriteria pengujiannya adalah sebagai berikut:

1. Jika $t_{\text {hitung }}>t_{\text {tabel }}$ maka Ho ditolak dan menerima Ha yang artinya variabel bebas (X) secara parsial mempengaruhi variabel terikat (Y).

2. Jika $t_{\text {hitung }}<t_{\text {tabel }}$ maka Ho diterima dan menolak Ha yang artinya variabel bebas (X) secara parsial tidak mempengaruhi variabel terikat (Y).

\section{Uji Statistik F (Uji Simultan)}

Uji F dilakukan untuk mengetahui apakah variabel bebas secara serentak mempengaruhi variabel terikat. Apabila uji $\mathrm{F}$ lebih besar dari nilai tabel $F$ maka variabel bebas secara keseluruhan berpengaruh terhadap variabel terikat (Gujarati, 2006). Adapun kriteria pengujian yang digunakan adalah sebagai berikut:

1. Jika $F_{\text {hitung }}>F_{\text {tabel }}$ maka Ho ditolak dan menerima Ha yang artinya variabel bebas (X) secara simultan mempengaruhi variabel terikat (Y).

3. Jika $F_{\text {hitung }}<F_{\text {tabel }}$ maka Ho diterima dan menolak Ha yang artinya variabel bebas (X) secara simultan tidak mempengaruhi variabel terikat (Y)

\section{Koefisien determinasi}

Koefisien determinasi $\left(R^{2}\right)$ pada intinya mengukur seberapa jauh kemampuan model dalam menerangkan variasi variabel terikat. Nilai koefisien determinasi adalah antara nol dan satu $\left(0<R^{2}<1\right)$. Nilai $R^{2}$ yang terkecil berarti kemampuan variabel-variabel independen dalam menjelaskan variasi variabel terikat amat terbatas. Nilai yang mendekati satu berarti variabelvariabel bebas memberikan hampir semua informasi yang dibutuhkan untuk memprediksi variasi variabel terikat (Gujarati, 2006).

\section{Koefisienkorelasi}

Menurut Widarjono, (2017) koefisien korelasi mengukur derajat keeratan antara dua variabel. Berikut ini ketentuan korelasi adalah: a. Bila $r=0$ atau mendekati 0 , maka korelasi antar kedua variabel sangat lemah atau tidak terdapat hubungan antara variabel $X$ terhadap variabel $Y$.

b. Bila $r=+1$ atau mendekati +1 , maka korelasi antar kedua variabel adalah kuat dan searah, dikatakan positif.

\section{Model Vactor Autogeression (VAR)}

Model Vactor Autogeression (VAR) merupakan salah satu metode time series yang digunakan dalam penelitian, terutama dalam bidang ekonomi. Model VAR adalah model linier sehingga kita tidak perlu khawatir tentang bentuk model serta model VAR mudah diestimasi dengan menggunakan metode OLS (Widarjono, 2017).

Adapun persamaan VAR dalam penelitian ini adalah sebagai berikut:

$P E_{t}=\alpha+\sum_{i=1} \beta_{1} P E_{t-i}+\sum_{i=1} \beta_{2} M D_{t-i}+$ $\sum_{i=1} \beta_{3} S K_{t-i}+\varepsilon_{t 1}$

\section{Keterangan :}

PE

MD

SK

$\varepsilon_{t 1}$

$\beta_{1}$

: Pertumbuhan konomi

: Minyak Dunia

: Suku Bunga

: Faktor Gangguan

: Konstantan

Tahapan Uji Model VAR (Widarjono, 2017) adalah sebagai berikut:

\section{Uji Stasioner}

Uji stasioneritas/ uji akar-akar unit (Unit Root Test) dilakukan untuk menentukan stasioner tidaknya sebuah variabel. Data dikatakan stasioner apabila data tersebut mendekati rata-ratanya, dan apabila data yang diamati dalam uji derajat integrasi (Integration Test) sampai memperoleh data yang stasioner. Bentuk persaman uji stasioneritas dengan analisis ADF (Augemented Dickey Fuller)

Apabila dalam pengujian ini menunjukkan nilai ADFstatistik lebih besar dari pada Mackinnon Critical Value maka data tersebut stasioner, dan sebaiknya apabila nila ADFstatistik lebih kecil dari pada Mackinnon Critical Value maka data tersebut tidak stasioner.

\section{Penentuan Lag Optimal}

Tahap kedua di dalam analisis VAR adalah penentuan lag optimum. Penentuan jumlah lag dalam model VAR ditentukan pada kriteria informasi yang direkomendasikan oleh nilai terkecil dari Final Prediction Error (FPE), Akaike 
Information Criterion (AIC), Schwarz Criterion (SC), dan Hannan-Quinn (HQ). Program Eviews telah memberi petunjuk tanda bintang bagi lag yang ditetapkan sebagai lag optimum.

\section{Uji Kausalitas Granger}

Metode yang digunakan untuk menganalisis hubungan kausalitas antar variabel yang diamati adalah dengan uji kausalitas Granger.Pengambilan keputusan dalam uji kausalitas dapat dilakukan dengan membandingkan nilai $t$-statistik hasil estimasi dengan nilai t-tabel atau dengan melihat nilai

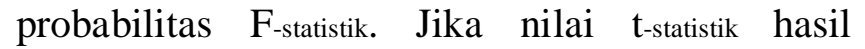
estimasi lebih besar dari nilai t-tabel atau nilai probabitas $\mathrm{F}$-statistik < $\alpha=5 \%$, maka $\mathrm{H}_{0}$ di tolak artinya terdapat pengaruh antara dua variabel yang diuji, dan begitu juga sebaliknya.

\section{Uji Kointegrasi}

Data time series seringkali menunjukkan kondisi yang tidak stasioner pada tingkat level (Widarjano, 2013). Namun seringkali menunjukkan stasioner melalui tingkat difference. Oleh karena itu perlu dilakukan uji kointegrasi untuk mengetahui apakah variabel bebas dan terikat terkointegrasi sehingga ada hubungan jangka panjang antar variabel. Dalam penelitian ini untuk melihat kointegrasi maka dilakukan melalui Johansen cointegrasi test. Apabila nilai trace statistic < critical value, begitu juga nilai max eign stat < critical value,ini berarti bahwa tidak terdapat kointegrasi di dalam model persamaan tersebut dan begitu pula sebaliknya.

\section{Uji Impulse Response}

IRF menunjukkan bagaimana respon dari setiap variabel endogen sepanjang waktu terhadap kejutan dari variabel itu sendiri dan variabel endogen lainnya. IRF dapat juga mengidentifikasikan suatu kejutan pada satu variabel endogen sehingga dapat menentukan bagaimana suatu perubahan yang tidak diharapkan dalam variabel mempengaruhi variabel lainnya sepanjang waktu. Oleh karena itu IRF dapat digunakan untuk melihat pengaruh kontemporer dari sebuah variabel dependen jika mendapatkan guncangan atau inovasi dari variabel independen sebesar saatu standar deviasi. Hasil IRF tersebut sangat sensitif terhadap pengurutan (ordering) variabel yang digunakan dalam perhitungan.

\section{Uji Forecast Error Variance decomposition (FEVD)}

Uji ini dilakukan untuk memberi informasi mengenai bagaimana hubunngan dinamis antara variabel yang dianalisis. Selain itu, FEVD ini dilakukan untuk melihat seberapa besar pengaruh acakk guncangan (random shock) dari variabel tertentu terhadap variabel endogen. FEVD menghasilkan informasi mengenai relatif pentingnya masing-masing inovasi acak (random innovation structural diturbance) atau seberapa kuat komposisi dari peranan variabel tertentu terhadap lainnya.

\section{HASIL DAN PEMBAHASAN}

\section{Perkembangan Pertumbuhan Ekonomi}

Pertumbuhan ekonomi merupakan proses kenaikan output per kapita dalam jangka panjang. Pengertian ini mengandung tiga hal pokok yaitu proses, output per kapita dan jangka panjang. Proses menggambarkan perkembangan ekonomi dari waktu ke waktu yang bersifat dinamis, output per kapita mengaitkan aspek output total dan aspek jumlah penduduk, dan jangka panjang menunjukkan kecenderungan perubahan perekonomian dalam jangka waktu tertentu yang di dorong oleh perubahan intern perekonomian. Berdasarkan data yang diperoleh maka pergerakan pertumbuhan ekonomi dari 1987-2017 bisa dilihat pada Gambar 5.

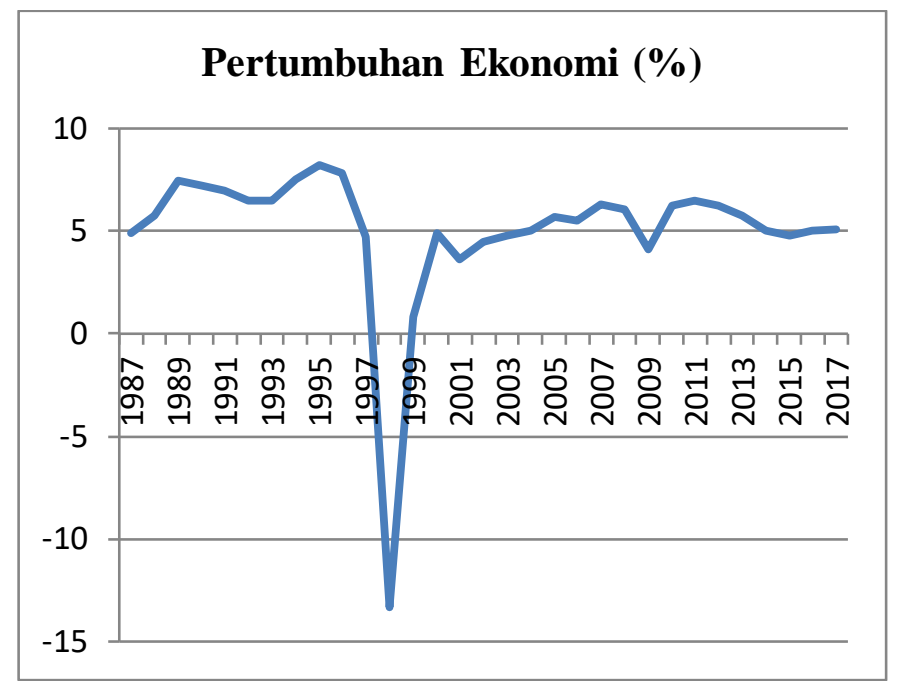

Sumber: Hasil Pengelolahan Data, (2019)

Gambar 5

Perkembangan Pertumbuhan Ekonomi

Berdasarkan Gambar 5 dapat kita lihat pertumbuhan ekonomi terendah pada tahun 1997, karena terjadinya krisis moneter yang sangat besar yang menyebabkan semua harga barang meningkat dan nilai tukar rupiah melemah, biasanya U\$\$ 1 sebesar Rp. 2500, sedangkan pada saat krisis tersebut mencapai Rp. 7.500 dan bahkan lebih. 
Berikutnya mulai stabil kembali pada pertengahan tahun 2000. Meningkatnya pertumbuhan ekonomi akan membuat pelaksanaan kegiatan perekonomian suatu Negara akan semakin lancar dan lebih baik dan mampu mempercepat pertumbuhan ekonomi masyarakat suatu Negara. Dan sebaliknya jika pertumbuhan ekonomi menurun ini akan berdampak negatif dikarenakan dapat menjadi penghambat dalam proses pembangunan perekonomian suatu Negara.

\section{Perkembangan Harga Minyak}

Kenaikan harga minyak dunia seharusnya berdampak pada terapresiasinya mata uang dalam negeri bagi kelompok negara pengekspor minyak dan sebaliknya berakibat pada tedepresiasinya mata uang dalam negeri bagi negara pegimpor minyak. Semakin besar permintaan suatu negara terhadap minyak mentah untuk memeuhi kebuthannya maka semakin tinggi impor negara tersebut, sehingga neraca perdagangannya akan mengalami penurunan. Sebaliknya, semakin besar penawaran suatu negara atas minyak mentah maka ekspor minyak negara tersebut akan mengalami peningkatan dalam neraca perdagangannya. Berdasarkan data yang diperoleh maka pergerakan minyak dunia dari 1987-2017 bisa dilihat pada Gambar 6

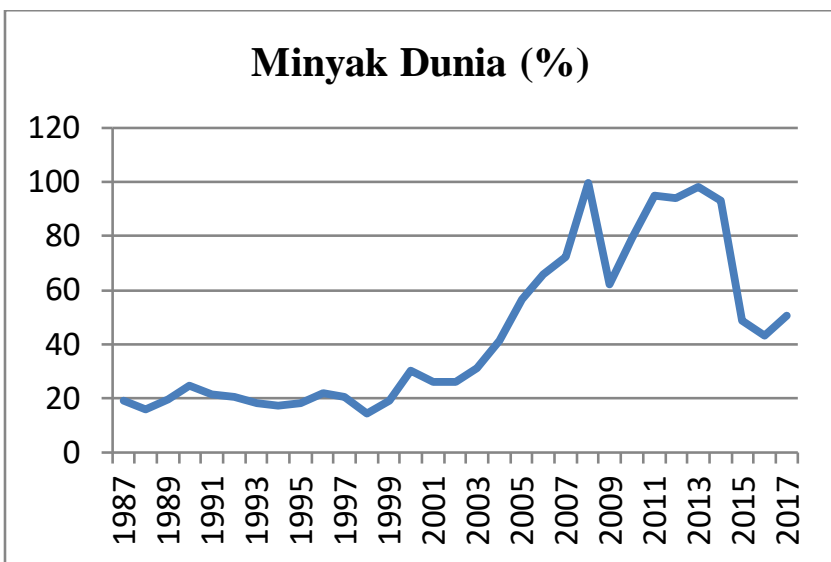

Sumber: Bank Indonesia, (2019)

\section{Gambar 6}

\section{Perkembangan Minyak Dunia}

Pada Gambar 6 perkembangan hargan minyak dunia dari tahun 1987-2017 secara keseluruhan dapat di katakan megalami fluktuasi, titik terendah terdapat pada tahun 1998 karena terjadi krisis moneter secara besar-besaran, kemudian mengalami kenaikan drastis tahun 2008, dan pada tahun 2009 mengalami penurunan kembali, namun pada tahun 2012 mengalami kenaikan kembali.

\section{Perkembangan Suku Bunga}

Suku bunga merupakan suku bunga acuan yang ditetapkan oleh Bank Indonesia untuk menjadi acuan dalam operasi moneter untuk mengarahkan agar menjadi acuan untuk bank-bank umum di Indonesia. semakin tinggi tingkat suku bunga maka akan mendorong menurunya investasi di negara tersebut, penurunan investasi dapat menurunnya pendapatan agregat dan berimbas ke cadangan devisa yang dimiliki negara tersebut. Berdasarkan data yang diperoleh, maka pergerakan suku bunga untuk periode 1997-2017 dapat dilihat pada Gambar 7 sebagai berikut:

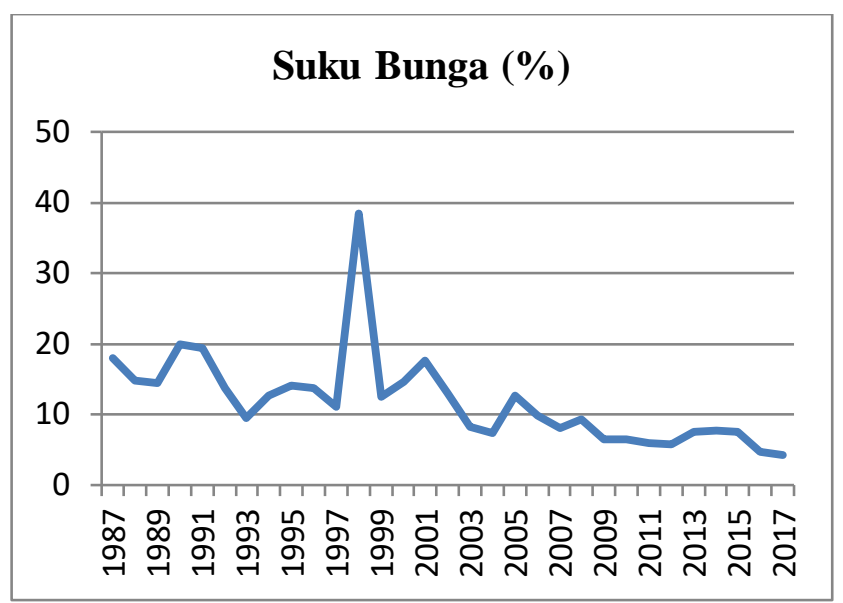

Sumber: Badan Pusat Statistik, (2019)

\section{Gambar 7}

PerkembanganSuku Bunga

Berdasarkan Gambar 7 Pada tahun 1998 terjadi krisis moneter harga-harga barang yang melonjak serta terjadinya kerusuhan hampir di seluruh wilayah Indonesia sehingga inflasi meningkat lebih dari $70 \%$ yang membuat suku bunga melambung tinggi. tingkat suku bunga tertinggi berada di 38,44 persen Bank Indonesia menetapkan targetnya untuk mengendalikan perekonomian sehingga defisit transaksi berjalan menurun ketingkat yang lebih sehat dan memperkuat kebijakan moneter serta pengendalian inflasi. Sedangkan pada tahun 2014 sampai April 2017 suku bunga menurun dari 7,75 sampai 4,25 persen dimana BI mempertahankan tren bunga terendah untuk mendorong penyaluran kredit bank sehingga mendorong ekonomi. yaitu kebijakan BI untuk menstabilkan perekonomian Indonesia di tengah kondisi ketidak pastian global.

\section{Hasil Penelitian \\ Model Regresi Linear Ordinary Least Square (OLS)}

Berikut hasil pengolahan regresi linier berganda adalah: 
Tabel 2

Hasil Pengolahan Data Regresi Linier Berganda

\begin{tabular}{ccccc}
\hline \hline Variable & Coefficient & Std. Error & t-Statistic & Prob. \\
\hline \hline C & 12.18112 & 1.886003 & 6.458697 & 0.0000 \\
MD & -0.037464 & 0.021109 & -1.774829 & 0.0868 \\
SK & -0.460745 & 0.093845 & -4.909622 & 0.0000 \\
\hline \hline \multicolumn{5}{c}{ Prob(F- } \\
R-squared & 0.478792 F-statistic & 12.86067 \\
Adjusted \\
R-squared & 0.441563 statistic) & 0.000109 & \\
\multicolumn{5}{c}{ Darbin- } \\
F-statistic & 12.86067 Watson stat & 0.82528 & \\
Prob(F- & & \\
statistic) & 0.000109 & \\
\hline \hline
\end{tabular}

Sumber: Hasil Pengolahan Data, 2019

$Y_{t}=\beta_{0}+b_{1} x_{1 t}+b_{2} x_{2 t}+\mathrm{et}$

$\mathrm{PEt}=12,181-0,038 \mathrm{MDt}-0,461 \mathrm{SKt}$

Adapun interprestasi persamaanya sebagai berikut:

1. Konstanta $\left(\beta_{0}\right)=12,181$

Apabila variabel minyak dunia dan suku bunga bernilai kostan (0), maka pertumbuhan ekonomi Indonesia akan konstan sebesar 12,181 persen.

2. Koefisien Regresi $\mathrm{MD}\left(\beta_{1}\right)=-0,038$

Apabila variabel minyak dunia meningkat sebesar 1 Dollar perbarrel, maka akan terjadi penurunan pertumbuhan ekonomi Indonesia sebesar 0,038 persen, dengan asumsi suku bunga konstan (cateris paribus).

3. Koefisien Regresi SK $\left(\beta_{2}\right)=-0,461$

Apabila variabel suku bunga meningkat sebesar 1 persen, maka mengakibatkan penurunan pertumbuhan ekonomi sebesar 0,461 persen. Dengan asumsi Harga minyak dunia konstan (cateris paribus).

\section{Uji Asumsi Klasik}

Uji asumsi klasik dalam penelitian ini terdiri atas:

\section{Uji Normalitas}

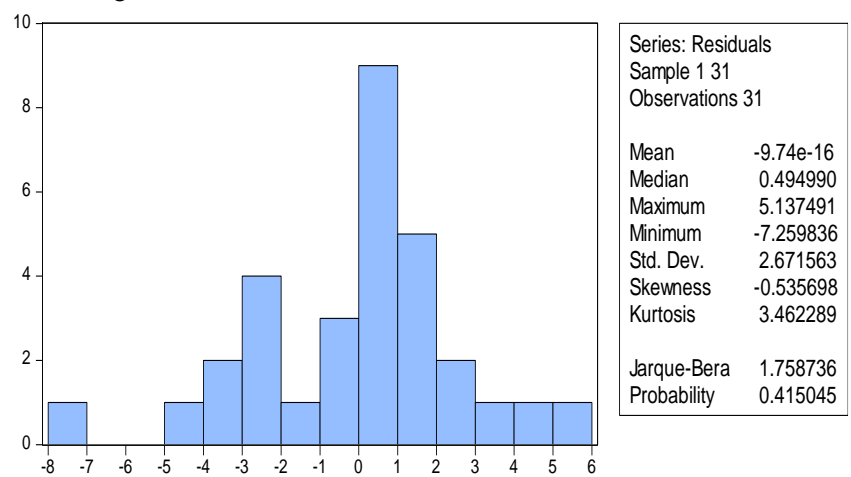

Sumber: Hasil Pengelolahan Data, 2019

Gambar 8

Uji Normalitas

Dari gambar diatas dapat disimpulkan bahwa hasil pengujian normalitas ini berdistribusi normal, terlihat pada nilai probability 0,42 lebih besar dari taraf kepercayaan 0,05 artinya data residual dalam model ini sudah terdistribusi normal.

\section{Uji Multikolineritas}

Tabel 3

\section{Uji Multikolineritas}

\begin{tabular}{|l|l|l|l|}
\hline Variabel & $\begin{array}{l}\text { R- } \\
\text { Squared }\end{array}$ & VIF & Tolerance \\
\hline $\begin{array}{l}\text { Minyak } \\
\text { Dunia }\end{array}$ & 0.329072 & 1.490473 & 0.670928 \\
\hline $\begin{array}{l}\text { Suku } \\
\text { Bunga }\end{array}$ & 0.329072 & 1.490473 & 0.670928 \\
\hline
\end{tabular}

Sumber: Hasil Pengelolahan Data, 2019

Berdasarkan hasil diatas nilai VIF semua variabel berada dibawah atau lebih kecil dari 10 yang berarti bahwa data terbebas dari multikolineritas. Begitu juga niali tolerance mendekati satu yang berarti terhindar dari multikolineritas.

\section{Uji Autokorelasi}

\section{Tabel 4}

\section{UJi Autokoralasi Metode LM Test}

Breusch-Godfrey Serial Correlation LM Test:

\begin{tabular}{llll}
\hline \hline F-statistic & 10.06064 & Prob. F(2,26) & 0.0006 \\
Obs*R-squared & 13.52434 & Prob. Chi-Square(2) & 0.0012 \\
\hline \hline
\end{tabular}

Sumber: Hasil Pengelolahan Data, 2019

Berdasarkan tabel 4 di atas dapat di jelaskan bahwa nilai obs*R-square 13,52 di bawah $x^{2}$ tabel pada $\alpha 5 \%$ dengan df $2=$ 5,99 jadi $13,52>5,9$ dan Prob sebesar $0,0012<0,05$. Dengan demikian dapat disimpulkan bahwa dalam model ini ada indikasi autokorelasi karena nilai Prob Chi-square lebih kecil dari taraf kepercayaan 0,05. 


\section{Uji Heteroskedastisitas}

Tabel 5

UJi Heteroskedastisitas

Heteroskedasticity Test: White

\begin{tabular}{llll}
\hline \hline F-statistic & 12.36819 & Prob. F(5,25) & 0.0000 \\
Obs*R-squared & 22.07564 & Prob. Chi-Square(5) & 0.0005 \\
Scaled explained SS & 22.17251 & Prob. Chi-Square(5) & 0.0005 \\
\hline \hline
\end{tabular}

Sumber: Hasil Pengelolahan Data, 2019

Berdasarkan hasil uji white-Test menggunakan program eviws 9, dapat dilihat bahwa nilai $o b s * R$-square sebesar 22,075> $>x^{2}$ tabel pada $\alpha 5 \%$ dengan df(5) 11,07 atau 22,075 $>11,07$ dimana dalam model ini ada indikasi heteroskedastisitas.

\section{Pengujian Uji Statistik}

\section{Uji Statistik $\mathbf{t}$}

Uji ini dilakukan dengan membandingkan nilai t-hitung dengan t-tabel. Dengan cara df (n$\mathrm{k})=(31-3)=28$ pada $\alpha 1 \%$ dan $\alpha 10 \%$ adalah sebesar 2,763=2,76 dan 1.70113=1,70.

Konstanta $\left(\beta_{0}\right)=6,46$, oleh karena $t_{\text {hitung }}>t_{\text {tabel }}$ atau $6,46>2,76$, maka tolak $H_{0}$ dan terima $H_{a}$ yang berarti bahwa variabel Minyak dunia dan Suku bunga berpengaruh secara signifikan dan positif terhadap pertumbuhan ekonomi. Hal ini juga dapat dilihat dari probabilitas (P-value) sebesar 0,0000 $<0,01$.

Parameter $\beta_{1}$ Minyak dunia $=-1,77$ oleh karena itu $t_{\text {hitung }}>t_{\text {tabel }}$ atau(- 1,77<-1,70), maka tolak $H_{0}$ dan terima $H_{1}$ yang berarti Minyak dunia berpengaruh secara signifikan dan negatif terhadap pertumbuhan ekonomi Indonesia. Hal ini juga bias dilihat dari probabilitas (P-value) sebesar $0.0868<0,1$.

Parameter $\beta_{2} \mathrm{SB}=-4,91$ oleh karena itu $t_{\text {hitung }}>t_{\text {tabel }}$ atau $(-4,91<-2,76)$ tolak $H_{0}$ dan terima $\mathrm{H}_{2}$ yang berarti suku bunga berpengaruh secara signifikan dan negatif terhadap pertumbuhan ekonomi Indonesia. Hal ini juga bias dilihat dari probabilitas (P-value) sebesar $0,0000<0,01$.

\section{Uji Statistik $F$}

Salah satu cara melakukan uji f adalah dengan membanding nilai $\mathrm{F}$ hitung dengan $\mathrm{F}$ tabel. Dengan cara df $(\mathrm{k}-1)(\mathrm{n}-\mathrm{k})=(3-1)(31-3)$ (2) $(28)=5,45$. Berdasarkan hasil Tabel $4.5 \mathrm{~F}$ statistik sebesar 12,86 oleh karena $f_{\text {hitung }}>f_{\text {tabel }}$ atau $12,86>5,45$, maka tolak $H_{0}$ dan terima $H_{a}$, jadi secara bersama-sama variabel minyak dunia dan suku bunga berpengaruh secara signifikan dan positif terhadap pertumbuhan ekonomi hal ini juga bias dilihat dari probabilitas (P-value) sebesar 0,0000 $<0,005$.

\section{Koefisien Determinasi $\left(R^{2}\right)$}

Dari hasil pengelolaan data diperoleh Adjusted R.Squared sebesar 0,4416 jadi besarnya pengaruh minyak dunia dan suku bunga terhadap pertumbuhan ekonomi di Indonesia adalah sebesar $44,16 \%$, sedangkan yang dipengaruhui oleh variabel lain diluar model ini adalah sebesar $0,5584(55,84 \%)$.

\section{Koefisien Korelasi}

Berdasarkan hasil pengolahan data pada tabel 2 diperoleh nilai korelasi (R) $\sqrt{R^{2}}=\sqrt{0,4788}=$ 0,6919 . Jadi hubungan variabel minyak dunia dan suku bunga terhadap pertumbuhan ekonomi berpengaruh kuat secara positif, karena nilai korelasi sebesar 0,6645 jauh positif atau $(+1)$.

Berdasarkan hasil uji pada model regresi linier berganda, ternyata pada uji asumsi klasik yaitu uji auto korelasi dan heteroskedastisitas di langgar karena pada model tersebut ada indikasi autokorelasi dan heteroskedastisitas, maka model di lanjutkan ke model Vactor Autoregression (VAR).

\section{Vactor Autoregression (VAR) Uji Stasioner}

Untuk mengetahui data time series yang digunakan stasioner atau tidak, digunakan uji akarakar unit (unit root test) dengan menggunakan metode Augmanted Dickey Fuller (ADF).

\section{Tabel 6}

\section{Uji Unit Root Test Model ADF}

\begin{tabular}{|c|l|c|c|c|c|}
\hline $\begin{array}{c}\text { Var } \\
\text { iabe } \\
1\end{array}$ & \multicolumn{1}{|c|}{$\begin{array}{c}\text { Unit } \\
\text { Root }\end{array}$} & $\begin{array}{c}\text { ADF test } \\
\text { Satistic }\end{array}$ & $\begin{array}{c}\text { Critical } \\
\text { Value 5\% }\end{array}$ & $\begin{array}{c}\text { Prob } \\
\text { ADF }\end{array}$ & $\begin{array}{c}\text { Keterang } \\
\text { an }\end{array}$ \\
\hline PE & Level & -3.856198 & -2.963972 & 0.0063 & Stasioner \\
\cline { 2 - 6 } & $\begin{array}{l}\text { First } \\
\text { Diff }\end{array}$ & -6.630877 & -3.574244 & 0.0000 & Stasioner \\
\hline MD & Level & -1.414268 & -2.963972 & 0.5620 & $\begin{array}{l}\text { Tidak } \\
\text { Stasioner }\end{array}$ \\
\cline { 2 - 6 } & $\begin{array}{l}\text { First } \\
\text { Diff }\end{array}$ & -5.650191 & -3.574244 & 0.0004 & Stasioner \\
\hline SK & Level & -3.657962 & -2.963972 & 0.0103 & Stasioner \\
\cline { 2 - 6 } & $\begin{array}{l}\text { First } \\
\text { Diff }\end{array}$ & -6.670675 & -3.580623 & 0.0000 & Stasioner \\
\hline
\end{tabular}

Sumber: Hasil Pengolahan Data, 2019

Berdasarkan tabel 6 bahwa variabel pertumbuhan ekonomi pada semua level intercept baik di level ataupun di firstdifferent pada taraf keyakinan $1 \%$ yang dibuktikan oleh nilai ADF lebih besar dari critical value 1\% yaitu $-3,86>-$ 2,96 dan $-6,63>-3,57$. Variabel minyak dunia tidak stasioner di tingkat level karena ADF lebih kecil dari critical value 5\% yaitu sebesar $-1,41<-2,96$ 
tetapi stasioner ditingkat firstdifferent pada $\alpha: 1 \%$ yaitu $-5,65>-3,57$. Kemudian variabel suku bunga stasioner tingkat level pada $\alpha ; 10 \%$ ataupun pada firstdifferent pada taraf keyakinan $1 \%$ yaitu $-3,65>-2,96$ dan $-6,67>-3,58$. dari satu pada lag 1 sehingga dapat disimpulkan bahwa model VAR yang dibentuk sudah stabil pada lag optimal yaitu lag 1 . Pada graph dapat dilihat bahwa titik invers roots of $A R$ polynominal semuanya berada dalam lingkaran.

\section{Uji Lag Optimum}

Tabel 7

Hasil Pengujian Lag Optimum

\section{Uji Kausalitas Granger}

\section{Tabel 8}

\section{Hasil Uji Kausalitas Granger}

\begin{tabular}{|c|c|c|c|c|c|c|c|c|c|}
\hline & & & & & & Null Hypothesis: & Obs & F-Statistic & Prob. \\
\hline 0 & -298.7279 & $\mathrm{NA}$ & 218659.1 & 20.80882 & 20.95026 & $\begin{array}{l}\text { 20.8531DPE does not Granger Cause DPE } \\
\text { Dranger Cause }\end{array}$ & 29 & 0.04790 & 0.8285 \\
\hline 1 & -263.3960 & $60.91697 *$ & $35757.20^{*}$ & $18.99283^{*}$ & $19.55861^{*}$ & 19.1700ஹD & & 0.03430 & 0.8545 \\
\hline 2 & -258.3847 & 7.603403 & 48215.32 & 19.26791 & 20.25802 & $19.578 \overline{\overline{0}}$ & \multirow{3}{*}{29} & & \\
\hline \multicolumn{6}{|c|}{ Sumber: Hasil Pengolahan Data, 2019} & $\begin{array}{l}\text { SK does not Granger Cause } \\
\text { DPE } \\
\text { DPE does not Granger Cause }\end{array}$ & & 0.34072 & 0.5644 \\
\hline \multirow{3}{*}{\multicolumn{6}{|c|}{$\begin{array}{l}\text { Dari tabel } 7 \text { nilai lag optimum terdapat } \\
\text { pada lag } 1 \text {, dimana pada lag ini terdapat kriteria } \\
\text { yaitu Likelihood Ratio (LR), Final Prediction } \\
\text { Error (FPE), Akaike Information Criterion (AIC), }\end{array}$}} & DSK & & 2.15848 & 0.1538 \\
\hline & & & & & & $\begin{array}{l}\text { DSK does not Granger Cause } \\
\text { DMD }\end{array}$ & 29 & 0.96290 & 0.3355 \\
\hline & & & & & & $\begin{array}{l}\text { DMD does not Granger Cause } \\
\text { DSK }\end{array}$ & & 7.92736 & 0.0092 \\
\hline
\end{tabular}

Hannan-Quin Criterion (HQ) dan jika diakumulasikan maka jumlah paling banyak bintang terletak pada lag 1 .

\section{Uji Stabilitas Vector Autoregression} Tabel 7

Hasil Uji Stabilitas Model

\begin{tabular}{cc}
\hline \hline Root & Modulus \\
\hline \hline 0.922807 & 0.922807 \\
0.506178 & 0.506178 \\
-0.087128 & 0.087128 \\
\hline \hline
\end{tabular}

Inverse Roots of AR Characteristic Polynomial

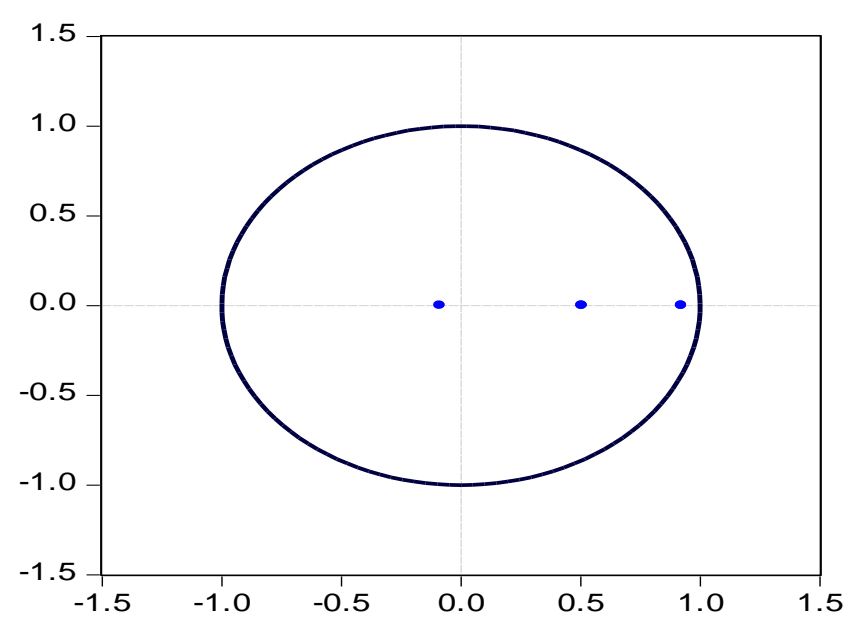

Sumber: Hasil Pengolahan Data, 2019

Keterangan : Pengujian Stabilitas VAR dengan Ar Roots Tabel dan Ar Root Graph

Berdasarkan hasil pengujian stabilitas Vector Autoregression pada tabel 7 menunjukkan bahwa persamaan VAR memiliki nilai modulus kurang
Sumber: Hasil Pengolahan Data, 2019

Berdasarkan Tabel 8 dapat kita lihat bahwa variabel minyak dunia tidak memiliki hubungan terhadap pertumbuhan ekonomi, begitu pun sebaliknya yang dibuktikan oleh prob kausalitas lebih besar dari tingkat keyakinan 5\% yaitu sebesar $0,83>0,05$ dan 0,85>0,05. Variabel suku bunga tidak memiliki hubungan terhadap pertumbuhan ekonomi dan sebaliknya yaitu 0,56>0,05 dan 0,15 $>0,05$. Kemudian variabel suku bunga terhadap minyak dunia tidak memilki hubunga kausalitas yaitu $0,33>0,05$ namun sbaliknya variabel minyak dunia terhadap suku bunga memiliki hubungan yaitu $0,009<0,05$ artinya memiliki hubungan satu arah. Hubungan kausalitas terjadi apabila setiap variabel memiliki hubungan dua arah signifikan pada level 5\% (probability > 0.05).

\section{Estimasi VAR}

Tabel 9

VAR Stability Condition Check

\begin{tabular}{cccc}
\hline \hline & DPE & \multicolumn{1}{c}{ DMD } & \multicolumn{1}{c}{ DSK } \\
\hline \hline \multirow{2}{*}{ DPE(-1) } & 0.492284 & -1.327002 & 0.231777 \\
& $(0.27644)$ & $(0.99422)$ & $(0.41827)$ \\
& {$[1.78082]$} & {$[-1.33472]$} & {$[0.55414]$} \\
& & & \\
DMD(-1) & 0.025452 & 0.757420 & -0.113285 \\
& $(0.03195)$ & $(0.11491)$ & $(0.04834)$ \\
& {$[0.79665]$} & {$[6.59161]$} & {$[-2.34345]$} \\
& & & \\
DSK(-1) & 0.191989 & -1.189093 & 0.092153 \\
& $(0.19985)$ & $(0.71879)$ & $(0.30239)$ \\
& {$[0.96064]$} & {$[-1.65431]$} & {$[0.30475]$}
\end{tabular}


C

$\begin{array}{rrr}-0.941330 & 32.93770 & 14.63047 \\ (4.65877) & (16.7555) & (7.04905) \\ {[-0.20206]} & {[1.96578]} & {[2.07552]}\end{array}$

Sumber: Hasil Pengolahan Data, 2019

Berdasarkan tabel 9 diatas, dengan t-tabel 2,0484 maka variabel minyak dunia berpengaruh positif dan tidak signifikan terhadap pertumbuhan ekonomi yaitu t-statistik lebih kecil dari t-tabel sebesar $0.79<2,05$. Variabel suku bunga berpengaruh positif dan tidak signifikan terhadap pertumbuhan ekonomi yaitu t-statistik lebih kecil dari t-tabel yaitu sebesar $0,96<2,05$ selama periode penelitian.

\section{Inpulse Respons Fungction}
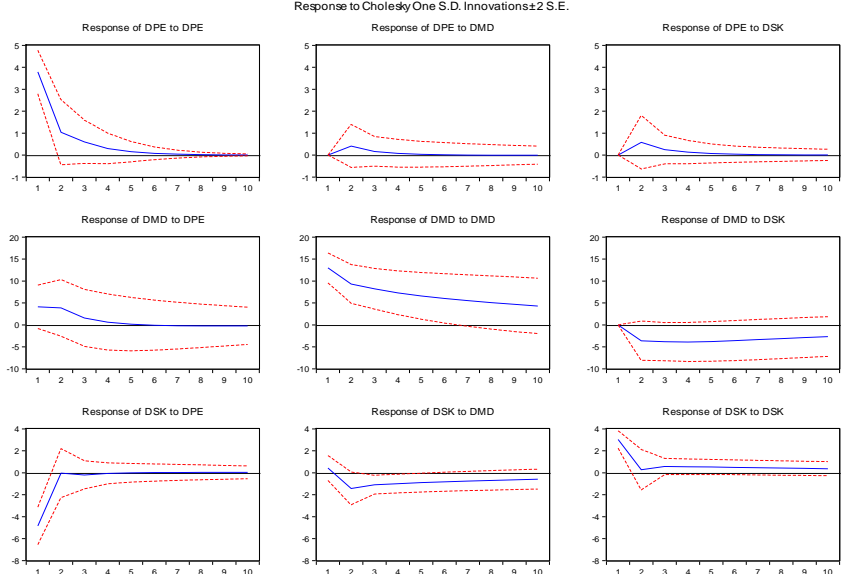

Response of DSK to DM
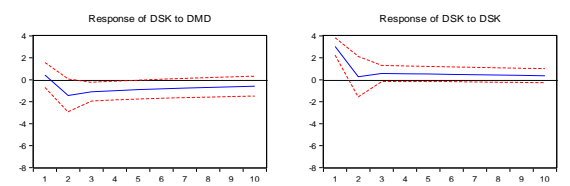

Sumber: Hasil Pengolahan Data, 2019

\section{Gambar 9 \\ Inpulse Response Fungction}

Berdasarkan hasil analisis inpulse respons dapat dilihat bahwa respon pertumbuhan ekonomi mengalami fluktuasi. Dimana ditahun pertama pertumbuhan ekonomi mengalami peningkatan dan terjadinya shock pada tahun kedua menyebabkan pertumbuhan ekonomi menurun signifikan serta mengalami shock lagi, dari tahun ke empat sampai tahun ke kelima yang menurun signifikan, dan pada tahun ke enam pertumbuhan ekonomi mencapai titik kesimbangannya. shock tersebut terjadi terhadap pertumbuhan ekonomi itu sendiri.

Respons minyak dunia terhadap pertumbuhan ekonomi pada awal mengalami peningkatan dan pada tahun ke tiga mengalami shock yang memyebakan minyak dunia menurun sehingga pada tahun ke lima minyak dunia mencapai titik kesimbangannya yaitu kembali stabil berarti membutuhkan waktu 2 bulan untuk kembali stabil. Serta respon suku bunga terhadap pertumbuhan ekonomi yaitu pada awal tahun suku bunga mengalami fluktuasi negatif sampai pada tahun ke dua suku bunga mengalami shock dan pada tahun ke tiga suku bunga kembali stabil berarti hanya membutuhkan waktu satu bulan untuk kembali stabil.

\section{Varian Decomposition}

Tabel 10

Variance Decomposition

\begin{tabular}{ccccc} 
Period & S.E. & DPE & DMD & DSK \\
\hline \hline 1 & 3.785962 & 100.0000 & 0.000000 & 0.000000 \\
2 & 3.990369 & 96.80023 & 1.071964 & 2.127805 \\
3 & 4.046696 & 96.34377 & 1.210376 & 2.445859 \\
4 & 4.060735 & 96.22037 & 1.241863 & 2.537764 \\
5 & 4.064356 & 96.18919 & 1.247116 & 2.563694 \\
6 & 4.065299 & 96.18071 & 1.247498 & 2.571789 \\
7 & 4.065554 & 96.17803 & 1.247356 & 2.574614 \\
8 & 4.065631 & 96.17686 & 1.247389 & 2.575755 \\
9 & 4.065661 & 96.17612 & 1.247583 & 2.576297 \\
10 & 4.065677 & 96.17555 & 1.247850 & 2.576599 \\
\hline \hline
\end{tabular}

Sumber: Hasil Pengolahan Data, 2019

Berdasarkan hasil analisis Variance Decomposition pertumbuhan ekonomi pada tabel 10 dapat dilihat pada awalnya pertumbuhan ekonomi masih sangat dipengaruhui oleh pertumbuhan ekonomi itu sendiri yaitu sebesar $100 \%$ dimana minyak dunia, dan BI Rate belum memberikan pengaruh sama sekali. Namun pada tahun-tahun selanjutnya kontribusi minyak dunia, dan BI Rate terus mengalami kenaikan hingga tahun ke 10 dimana minyak dunia sebesar 1.25 persen, dan BI Rate sebesar 2.58 persen,. Hal ini mengikuti penurunan proporsi shock pertumbuhan ekonomi terhadap pertumbuhan ekonomi itu sendiri, namun sampai tahun ke 10 kontribusinya masih relatif besar yakni 96.18 persen.

\section{Pembahasan}

\section{Hubungan Minyak Dunia Terhadap Pertumbuhan Ekonomi}

Berdasarkan hasil penelitian yang telah dilakukan dengan menggunakan dua model analisis yaitu regresi linier berganda dan Vecto Autoregression (VAR). Maka, diperoleh hasil dari regresi linier berganda adalah minyak dunia dan berpengaruh secara signifikan dan positif terhadap pertumbuhan ekonomi hal ini sesuai dengan pendapat (Afdi, 2012) yang mengatakan bahwa apabila fluktuasi harga minyak dunia berdampak positif terhadap pertumbuhan ekonomi.

Sedangkan hasil dengan menggunakan Vector autoregression (VAR) yaitu minyak dunia berpengaruh positif dan tidak signifikan terhadap pertumbuhan ekonomi. Hal ini sesuai dengan 
penelitian yang dilakukan oleh (Aprilita, 2011), dan Edirneligil, 2014).

\section{Hubungan \\ TerhadapPertumbuhan Ekonomi}

Bunga

Berdasarkan hasil penelitian yang telah dilakukan dengan menggunakan dua model analisis yaitu regresi linier berganda dan Vector Autoregression (VAR). Maka, diperoleh hasil dari regresi linier berganda adalah suku bunga berpengaruh secara signifikan dan positif terhadap pertumbuhan ekonomi Indonesia. Hal ini sesuai dengan pendapat (Indriyani, 2016) yang menyatakan bahwa suku bunga berpengaruh positif dan signifikan terhadap pertumbuhan ekonomi.

Sedangkan hasil dengan menggunakan Vector Aautoregression (VAR) yaitu suku bunga berpengaruh positif dan tidak signifikan terhadap pertumbuhan ekonomi. Hal ini sesuai dengan penelitian yang dilakukan oleh tuwonusa, (Rotin \& Mandeyij, 2016) menyatakan bahwa suku bunga berpengaruh secara positif dan tidak signifikan terhadap pertumbuhan ekonomi.

\section{Hubungan Ekspor Terhadap Pertumbuhan Ekonomi}

Berdasarkan hasil pengujian yang telah dilakukan dapat disimpulkan bahwa aekspor berpengaruh negatif dan tidak signifikan terhadap pertumbuhan ekonomi. Adanya pengaruh antara Ekspor dan pertumbuhan ekonomi berbanding balik, menurut teori yaitu jika Ekspor meningkat maka pertumbuhan ekonomi akan meningkat begitu juga sebaliknya jika Ekspor turun maka pertumbuhan ekonomi juga ikut menurun.

Penelitian ini sejalan dengan penelitian yang dilakukan Anggraeni, (2011) dengan judul penelitian pengaruh ekspor, impor dan investasi terhadap pertumbuhan ekonomi di kepulauan riau tahun 2009-2016 Variabel ekspor secara parsial tidak memiliki pengaruh secara signifikan terhadap pertumbuhan ekonomi Kepulaua Riau. Begitu juga dengan penelitian Pridayanti, (2012) yang berjudul pengaruh ekspor, impor dan nilai tukar terhadap pertumnuhan ekonomi indonesia. Dimana variabel ekspor berpengaruh negatif terhadap pertumbuhan ekonomi di Indonesia.

Penelitian ini tidak sejalan dengan penelitian Larasati \& Sulastmiyati, (2018) meneliti tentang pengaruh Inflasi, Ekspor dan Tenaga Kerja terhadap PDB, dimana variabel Ekspor berpengaruh positif dan signifikan terhadap PDB. Begitu juga dengan penelitian Kristiawati, (2013) penelitian tentang pengeruh
Ekspor, Nilai Tukar dan Inflasi terhadap Pertumbuhan Ekonomi di Indonesia, dimana variabel Ekspor berpengaruh negatif dan signifikan terhadap pertumbuhan ekonomi.

\section{KESIMPULAN DAN SARAN Kesimpulan}

Berdasarkan hasil penelitian yang telah dilakukan dengan menggunakan dua alat análisis yaitu model regresi linier berganda dan model VAR, maka dapat diambil kesimpulannya adalah sebagai berikut:

1. secara parsial Minyak Dunia berpengaruh secara signifikan dan negatif terhadap pertumbuhan ekonomi Indonesia, dan variabel suku bunga berpengaruh secara signifikan dan negatif terhadap pertumbuhan ekonomi Indonesia. Secara simutan variabel minyak dunia dan suku bunga berpengaruh secara signifikan dan positif terhadap pertumbuhan ekonomi

2. Berdasarkan model var variabel minyak dunia berpengaruh positif dan tidak signifikan terhadap pertumbuhan ekonomi, suku bunga berpengaruh positif dan tidak signifikan terhadap pertumbuhan ekonomi.

\section{Saran}

Berdasarkan kesimpulan yang telah dikemukakan di atas maka yang menjadi saran dalam penelitian ini adalah:

1. Berdasarkan hasil penelitian terlihat bahwa kenaikan harga minyak di pasar internasional nampaknya sudah bukan lagi menjadi berkah bagi Indonesia. Oleh karena itu pemerintah dan semua pemangku kepentingan harus berkolaborasi dalam upaya mengurangi atau mengeliminasi pengaruh guncangan harga minyak dunia di dalam negeri, langkah kongkret yang perlu segera di upayakan adalah menstaformasikan kebiasaan yang semula boros BBM menjadi hemat BBM. Selain itu, yang menjadi suatu program bagi pemerintah adalah menempuh kebijakan yang mendorong pengembangan sumber energi alternatif yang komprehensif dari hulu sampai hilir, karena indonesia kaya dengan sumber energi, baik yang berasal dari panas bumi seperti batu bara, matahari, angin maupun sumber energi yang menggunakan minyak nabati seperti minyak kelapa sawit. Kebijakan pengembangan energi alternatif ini perlu di lakukan mengingat indonesia saat ini telah menjadi impoertir minyak (net impoerter). Dalam kondisi minyak internasionl yang tinggi impor minyak akan 
menambah biaya produksi dan selanjutnya berdampak pada kenaikan harga barangbarang.

2. Mengingat variabel bebas dalam penelitian ini merupakan hal yang penting dalam meningkatkan perekenomian Indonesia sehingga diharapkan hasil penelitian ini dapat dipakai sebagai acuan untuk mengembangkan penelitian ini dapat dipakai sebagai acuan untuk mengembangkan penelitian selanjutnya dengan mempertimbangkan variabel-variabel lain yang tidak ada dalam penelitian ini.

\section{DAFTAR PUSTAKA}

Afdi, N. M. (2012). Dampak Fluktuasi harga Minyak Dunia Terhadap Perekonomian Indonesia.

Antasari, \& Soleh. (2012). Pengaruh Pengeluaran Pemerintah Terhadap Pertumbuhan ekonomi di Provinsi bengkulu. Ekombis Review, 117127. Retrieved from http://jurnal.unived.ac.id/index.php/er/article /view/139

Arifin, Y. (2018). Pengaruh Harga Minyak Dunia, Nilai tukar, dan Inflai Terhadap Pertumbuhan Ekonomi Indonesia. Economics Development Analysis Journal, 5(4), 474-483.

Boediono. (2014). Ekonomi Internasional Pengantar Ilmu Ekonomi No.3. BPFE UGM.

Brigham, F., \& Houston, J. (2001). DAsar-dasar Manajemen Keuangan. Jakarta: Salemba Empat.

Indriyani, S. N. (2016). Analisis Pengaruh Inflasi dan Suku Bunga Terhadap Pertumbuhan Ekonomi di Indonesia Tahun 2005-2015. Jurnal Manajemen Bisnis Krisnadwipayana, 4(2).

Judisseno, R. K. (2002). Sistem Moneter dan Perbankan Indonesia. Jakarta: Grahamedia Pustaka Utama.

Kristiawati. (2013). Pengaruh Ekspor, nilai Tukar, dan Inflasi Terhadap Pertumbuhan Ekonomi di Indonesia Taun 1995-2011. Jurnal Economic, 1(4).

Kurihara, Y. (2015). Title: Oil prices and Economic Growth in Developed Countries. Internasional Journal of Business and Social Science, 6(11), 40-46.

Larasati, I. S., \& Sulastmiyati. (2018). Pengaruh Inflasi, Ekspor, dan Teaga Kerja Terhadap PDB. Jurnal Administrasi Bisnis (JAB), 63(1).
Mishkin, F. S. (2008). Ekonomi Uang, Perbankan, dan Pasar Keungan Edisi 8. Jakarta: Salemba Empat.

Nasrullah. (2014). Analisis Pengaruh Perdagangan Internasional Terhadap Pertumbuhan Ekonomi Indonesia Tahun 1999-2013. Jurnal Ekonomi \& Studi Pembangunan, 1(6). https://doi.org/10.1017/CBO9781107415324.0 04

Ningtyas, M. S. A., \& Hidayat, R. R. (2014). Pengaruh Harga Minyak Dunia, Harga Emas, dan Tingkat Inflasi Terhadap Pertumbuhan Ekonomi Indonesia, Studi Pada Bank Indoneia Perode Tahun 2003-2012. Jurnal Administrasi Binis, 10(1), 1-8.

Septiawan, D. A., Hidayat, R. R., \& Sulasmiyati, S. (2016). Pengaruh Harga Minyak Dunia, Inflasi, dan Nilai Tukar Terhadap Pertumbuhan Ekonomi Indonesia (Studi Pada Tahun 2007-2014). Jurnal Administrasi Bisnis, 40(2), 130-138.

Widarjono, A. (2018). Ekonometrika edisi keempat. Yogyakarta: UPP STIM YKPN. 